\title{
PROBLEM DAN PENGATURAN CYBERCRIME MELALUI AKTIFITAS INTERNET DALAM KASUS SARA DI PILKADA SERENTAK 2018
}

\author{
Bonanda Japatani Siregar \\ Fakultas Hukum Universitas Muslim Nusantara Al Washliyah \\ Siregarbonanda88@yahoo.com
}

\begin{abstract}
Abstrak
Kecenderungan Cyber Crime di Indonesia masih seputar kebencian dan intoleransi rasis yang berimplikasi pada stabilitas negara. Begitu banyak kasus etnisitas, agama, ras dan hubungan antarkelompok terjadi di Indonesia, terutama dalam pemilihan tahun 2018 bersamaan dengan potensi konflik sara ini. rentan terjadi. Menurut penulis konflik Sara sangat berbahaya, karena efek konflik suku, agama, ras dan antar-kelompok ini dapat memecah belah masyarakat dan bahkan bangsa. Studi ini tentang literatur makanan dengan sendirinya adalah normatif. Penelitian ini bertujuan untuk mengetahui bagaimana problem dan pengaturan cybercrime melalui aktivitas internet dalam kasus sara di Pilkada serentak 2018 , dan faktor-faktor apa saja penyebab cybercrime melalui aktivitas internet dalam kasus sara di pilkada serentak 2018. Hasil penelitian ini menunjukkan bahwa problem dan pengaturan cybercrime melalui aktivitas internet dalam kasus sara di pilkada serentak 2018 dalam penerapannya lebih tepat menggunakan Pasal 28 ayat (2) UU Nomor 11 Tahun 2008 tentang Informasi dan Transaksi Elektronik. dengan ketentuan sanksi pidana pasal 28 ayat (2) diatur dalam Pasal 45 ayat (2)
\end{abstract}

Kata kunci: cybercrime, SARA, UU No 11 tahun 2008, pilkada 2018

\begin{abstract}
The tendency of Cyber Crime in Indonesia is still around hatred and racial intolerance that implications on the stability of the country. so many Case ethnicity, religion, race and inter-group relations occurred in Indonesia, especially in elections in 2018 simultaneously this potential conflict sara vulnerable occur. According to the writer Sara conflict is very dangerous, because the effects of this ethnicity, religion,race and intergroup relations conflict can divide the community and even the nation. This study concerning food literatures by itself is normative. This study aims to find out how law enforcement cybercrime against perpetrators of criminal in Pilkada 2018 simultaneously and the factors of any cause of cybercrime ethnicity, religion, race and inter-group relations in elections 2018 simultaneously. The results of this study showed that the enforcement of Cybercrime ethnicity, religion,race and inter-group relations law in elections 2018 simultaneously in its application more appropriate use Article 28 paragraph (2) of Law No. 11 Year 2008 on Information and Electronic Transactions with the provisions of criminal sanction article 28 paragraph (2) is regulated in Article 45 paragraph (2)
\end{abstract}

Keywords: cybercrime, SARA, UU No 11 tahun 2008, pilkada 2018

\section{PENDAHULUAN}

\subsection{Latar Belakang Masalah}

Teknologi informasi saat ini menjadi pedang bermata dua, karena selain memberikan kontribusi bagi peningkatan kesejahteraan, kemajuan dan peradaban manusia, sekaligus menjadi sarana efektif perbuatan 
melawan hukum. Menurut Soerjono Soekanto, kemajuan di bidang teknologi akan berjalan bersamaan dengan munculnya perubahan perubahan di bidang kemasyarakatan. Perubahanperubahan di dalam masyarakat dapat mengenai nilai sosial, kaidahkaidah sosial, pola-pola perikelakuan, organisasi, dan susuna kelembagaan masyarkat.

Saat ini telah lahir suatu rezim hukum baru yang dikenal dengan hukum siber. Istilah "hukum siber" diartikan sebagai padanan kata dari Cyber Law, yang saat ini secara internasional digunakan untuk istilah hukum yang terkait dengan pemanfaatan teknologi informasi. Istilah lain yang juga digunakan adalah hukum Teknologi Informasi (Law of 2 Information Technology) Hukum Dunia Maya (Virtual World Law) dan Hukum Mayantara. Istilahistilah tersebut lahir mengingat kegiatan internet dan pemanfaatan teknologi informasi berbasis virtual.

Barda Nawawi Arief menyebutkan bahwa tindak pidana yang terjadi di dunia maya dinamakan dengan cyber crime.Menurut Barda Nawawi Arief cyber crime merupakan salah satu bentuk atau dimensi baru dari kejahatan masa kini yang mendapat perhatian luas di dunia internasional. Serlanjutnya Barda Nawawi Arief mengatakan bahwa dalam perspektif hukum pidana, upaya penaggulangan cyber crime dapat dilihat dari berbagai aspek, diantaranya yaitu aspek kebijakan kriminalisasi (formulasi tindak pidana), aspek pertanggungjawaban pidana atau pemidanaan (termasuk aspek alat bukti/ 3 pembuktian), dan aspek yurisdiksi.
Istilah SARA adalah singkatan Suku, Agama, Ras dan Antar Golongan yang pada prinsipnya telah diatur di dalam Undang-undang serta segala peraturan pelaksananya. Salah satu Undang-undang yang mengaturnya adalah UUD 1945 yang merupakan sumber utama hukum di Indonesia. Kitab Undang-undang Hukum Pidana (KUHP) juga mengatur soal penyebaran kebencian dalam dimensi SARA yakni terdapat dalam pasal 156, pasal 156a dan pasal 157. Dalam perkembangannya, dibentuk pula Undang-undang No 40 tahun 2008 tentang Penghapusan Diskriminasi RAS dan Etnis atau dikenal dengan UU Anti Diskriminasin dalam menindak penyebaran kebencian SARA.

Namun, dua Undang-undang tersebut dinilai belum efektif dan dalam prakteknya masih menemui batasan dalam pengeimplementasianya, khususnya menyangkut Penegakan Hukum bagi mereka yang melakukan pelanggaran dengan menjadikan SARA sebagai kontennya.

Dalam hal ini kemudian lahirlah Undang - Undang No 11 Tahun 2008 Tentang Informasi dan Transaksi Elektronik, Pasal 28 ayat (2) merupakan ketentuan yang mulai digunakan dalam kasus kasus penyebaran kebencian berbasis SARA

Bunyi Pasal 28 ayat (2) UU ITE adalah sebagai berikut:

"Setiap Orang dengan sengaja dan tanpa hak menyebarkan informasi yang ditujukan untuk menimbulkan rasa bencian atau permusuhan individu dan/atau kelompok masyarakat tertentu berdasarkan atas suku, agama, ras,dan antar golongan (SARA)." 


\begin{abstract}
Menurut penulis kecendrungan Cyber Crime di Indonesia masih di seputaran kebencian dan Sara yang berimpilkasi pada stabilitas Negara. Masyarakat Indonesia masih melihat dunia internet sebagai dunia yang tidak memiliki etiket, yang di maksud dengan etiket adalah suatu sikap seperti sopan santun atau aturan lainya yang megatur hubungan antara kelompok manusia yang beradab dalam pergaulan. Kita sudah melihat bagaimana internet dimanfatkan untuk oleh satu pihak untuk menjatuhkan pihak lain atau sebaliknya sehinggan meresahkan masyarakat dan menganggu stabilitas wilayah.
\end{abstract}

Sudah banyak kasus sara terjadi Indonesia, apalagi di Pilkada serentak tahun 2018 ini potensi konflik SARA rentan terjadi. Menurut saya konflik Sara ini sangat berbahaya sekali, karena efek dari konflik sara ini bisa memecah belah masyarakat bahkan bangsa. Salah satu cara upaya untuk mengurangi potensi konflik sara yang rentan terjadi di pilkada serentak tahun 2018 dengan cara tidak membedabedakan dalam Penegakan hukumnya.

\subsection{Rumusan Masalah}

1. Bagaimana Penegakan hukum cybercrime terhadap tindak pidana SARA di pilkada serentak 2018

2. Faktor-faktor apakah yang mempengaruhi penegakan hukum cyber crime terhadap tindak pidana sara?

\section{METODE}

Peneltian hukum dibagi menjadi dua aspek yakni penelitian hukum yang aspeknya normatif dan peneltian hukum yang aspeknya empris. Peneltian ini menyangkut Kepustakaan maka dengan sendirinya merupaka peneltian normatif dengan cara mengambil data melalui Buku-Buku yang berkaitan dengan CyberCrime, Tulisan di Jurnal-jurnal dan dari berbagai peraturan perundang-undangan, serta Makalah dan tulisan-tulisan lainya yang relevan.

\section{HASIL DAN PEMBAHASAN}

\subsection{Penegakan Hukum CyberCrime terhadap tindak pidana SARA di pildaka serentak 2018}

Menurut Soerdjono Soekanto, Penegakan hukum adalah kegiatan menyerasikan hubungan nilai-nilai yang terjabarkan di dalam kaidahkaidah yang mantap dan sikap tindak sebagai rangkaian penjabaran nilai tahap akhir, untuk menciptakan, memelihara dan mempertahankan kedamaian pergaulan hidup. Hukum Merupakan sarana yang didalamnya terkandung nilai-nilai atau konsep tentang keadilan, kebenaran dan kemanfaatan social. Sedangkan Bellefroid mengemukakan bahwa hukum adalah segala aturan yang berlaku dalam masyarakat mengatur tata tertib masyarakat dan didasarkan atas kekuasaan yang ada dalam masyarakat. Kandungan Hukum itu bersifat abstarak. Menurut Sarjipto Raharjo, penegakan hukum pada hakekatnya merupakan penegakan ide-ide atau konsep yang abstrak itu. Penegakan hukum secara konkrit adalah berlakunya hukum positif dalam praktek sebagaimna seharusnya patut ditaati.

Dalam upaya menangani Cybercrime terhadap pelaku tindak 
pidana SARA di pilkada serentak 2018 para penegak hukum melakukan analogi atau perumpamaan dan persamaan terhadap pasal-pasal yang ada dalam KUHP biasanya digunakan lebih dari satu pasal. Penerapan pasal-pasal ini harus lebih tepat, sehingga sangat efektif dalam proses penegakan keadilan, namun disisi lain tidak melarang kebebesan berekpresi dan berpendapat. Pasal 28 ayat ( 2 ) Undang-Undang No 11 Tahun 2008 Tentang Informasi dan Transaksi Elektronik merupaka pasal yang paling tepat dalam menindak penyebaran kebencian disbanding pasal-pasal pidana lainya.

Pasal tersebut berbunyi: Setiap Orang dengan sengaja dan tanpa hak menyebarkan informasi yang ditujukan untuk menimbulkan rasa bencian atau permusuhan individu dan/atau kelompok masyarakat tertentu berdasarkan atas suku, agama, ras, dan antar golongan (SARA)." Ketentuan sanksi pidana pasal 28 ayat (2) tersebut diatur dalam pasal 45 ayat (2) berbunyi : "Setiap orang yang memenuhi unsur sebagaimana di maksud dalam pasal 28 ayat (1) atau ayat (2) dipidana dengan pidana penajara paling lama 6 tahun dan/ atau denda paling banyak 1 miliar rupiah." Maksud dan tujuan dari Pasal 28 ayat (2) ini pada prinsipnya adalah untuk mencegah terjadinya permusuhan, kerusuhan atau bahkan perpecahan yang didasarkan pada SARA.

Hukum di ciptakan oleh pemegang otoritas kekuasaan sebagai suatu sistem pengawasan prilaku manusia. Sebagai norma ia bersifat mengikat bagi tiap-tiap individu untuk tunduk dan mengikuti segala kaidah yang terkandung didalamnya. Keberadaan cyber law, dalam konteks ini berlaku bagi para netter yang berinteraksi di cyber space. Agar hukum itu berfungsi maka harus memenuhi syarat berlakunya hukum sebagai kaidah yakni.

1. Kaidah hukum berlaku secara yuridis, apabila penentuannya didasarkan pada kaidah yang lebih tinggi tingkatnya atau terbentuk atas dasar yang telah di tetapkan;

2. Kaidah hukum berlaku secara sosiologis, apabila kaidah tersebut efektif. Artinya, kaidah itu dapat dipaksakan berlakunya oleh penguasa walaupun tidak diterima oleh warga masyarakat ( teori kekuasaan ) atau kaidah itu berlaku karena adanya pengakuan dari masyarakat;

3. Kaidah hukum berlaku secara filosofis, yaitu sesuai dengan cita hukum sebagai nilai positif yang tertinggi.

\subsection{Faktor-faktor yang Memepangaruhi Penegakan Hukum CyberCrime terhadap tindak pidana sara}

Hukum tumbuh bukan dari perbuatan pemerintah, tetapi dari fakta-fakta sosial di dalam suatu komunitas. Aturan hukum merupakan pencerminan kaidahkaidah ekonomi dan moral yang didasarkan pada pengakuan masyarakat tentang kesignifikanannya bagi ikatan masyarakatnya. Oleh sebab itu keberadaan aturan yang mengatur mengenai prostitusi cyber didasarkan pada kaidah ekonomi dan moral. Hukum diciptakan oleh pemegang otoritas kekuasaan sebagai suatu sistem pengawasan perilaku manusia. Sebagai norma ia bersifat mengikat bagi tiap-tiap individu untuk tunduk 
dan mengikuti segala kaidah yang terkandung di dalamnya. Keberadaan cyber law, dalam konteks ini berlaku bagi para netter yang berinteraksi di cyber space.

Secara sosiologis, masyarakat memang memerlukan Undangundang Nomor 11 Tahun 2008 Tentang Informasi dan Transaksi Elektronik untuk mengatur berbagai aktivitas yang mereka lakukan selama berinteraksi di cyber space. Dinamika globalisasi informasi telah menuntut adanya suatu aturan untuk melindungi kepentingan para netter dalam mengakses pelbagai informasi. Pengaturan dalam Undang-undang Nomor 11 Tahun 2008 Tentang Informasi dan Transaksi Elektronik ini sejalan dengan agama, nilai-nilai maupun kaidah moral yang diterima secara universal sehingga keberadaan cyber law diakui, diterima dan dilaksanakan oleh information society. Kepastian hukum atau Rechtssicherkeit adalah sesuatu yang baru yaitu sejak hukum dituliskan, dipositifkan dan menjadi publik. Kepastian hukum adalah sicherkeit des scherts selbst (kepastian tentang hukum itu sendiri).

Ada empat hal yang berhubungan dengan kepastian hukum yakni pertama, bahwa hukum itu positif, artinya bahwa ia adalah perundang-undangan (gesetzliches recht). Kedua, bahwa hukum ini didasarkan pada fakta (tatsachen), bukan suatu rumusan tentang penilaian yang nantinya akan dilakukan oleh hakim seperti "kemauan baik", "kesopanan". Ketiga, bahwa fakta itu harus dirumuskan dengan cara yang jelas sehingga menghindari kekeliruan dalam pemaknaan, di samping juga dijalankan. Keempat, hukum positif itu tidak boleh sering diubah-ubah.
Dengan demikian kehadiran Undangundang Nomor 11 Tahun 2008 Tentang Informasi Elektronik diharapkan dapat menjadi alat untuk mencapai tujuan hukum yakni keadilan, kemanfaatan dan kepastian hukum.

Pencegahan dan penanggulangan terhadap tindak pidana SARA di pilkada serebtak 2018 membutuhkan pendekatan penal dan non penal yang integralistik dan membutuhkan keterpaduan. Membicarakan masyarakat adalah suatu keharusan yang melekat pada perbincangan mengenai hukum. Hukum dan masyarakatnya merupakan dua sisi dari satu mata uang. Maka tanpa perbincangan mengenai masyarakat terlebih dahulu, sesungguhnya berbicara tentang hukum yang kosong. Penegakan hukum berasal dari masyarakat dan bertujuan untuk mencapai kedamaian di dalammasyarakat. Oleh karena itu, dipandang dari sudut tertentu, maka masyarakat dapat mempengaruhi penegakan hukum tersebut. Pengaruh masyarakat dalam penegakan hukum ini ditelaah dari kesadaran hukum yang menjadi indikator dari derajat kepatuhan hukum. Kesadaran hukum sangat diperlukan dalam berteknologi. Teknologi informasi merupakan ujung tombak dari globalisasi. Kondisi ini melahirkan suatu dunia baru yang disebut global village (desa global). Kemajuan dan perkembangan teknologi, khususnya telekomunikasi, multimedia dan teknologi informasi pada akhirnya akan mengubah tatanan organisasi dan hubungan sosial kemasyarakatan.

Mengenai kendala yang pertama yaitu mengenai proses penaatan terhadap hukum, jika 
masyarakat di Indonesia memiliki pemahaman yang benar akan tindak pidana cyber crime maka baik secara langsung maupun tidak langsung masyarakat akan membentuk suatu pola penaatan. Pola penaatan ini dapat didasarkan karena ketakutan akan ancaman pidana yang dikenakan bila melakukan perbuatan cyber crime atau pola penaatan ini tumbuh atas kesadaran mereka sendiri sebagai masyarakat hukum. Melalui pemahaman yang komprehensif mengenai cyber crime, peran masyarakat menjadi sangat penting dalam upaya pengawasan, ketika masyarakat mengalami lack of information, peran mereka akan menjadi mandul.

\section{KESIMPULAN}

Penegakan Hukum cybercrime terhadap tindak pidana sara di pilkada serentak 2018 adalah kegiatan menyerasikan hubungan nilai-nilai yang terjabarkan di dalam kaidah-kaidah atau pandnaganpandnagan nilai yang mantap terhadap kejahatan dunia maya, yakni perbuatan hukum melawan yang dilakukan dengan menggunakan internet yang berbasis pada kecanggiha teknologi computer dan telekomunikasi. Ada beberapa factor yang memepangaruhi Penegakan Hukum cybercrime, yaitu : Faktor Hukumnya sendiri, factor penegak hukum, factor budaya, factor masyarakat dan factor politik.

Adapun hambatan-hambatan yang ditemukan di dalam proses Penegakan yang Hukum cybercrime yaitu Dalam upaya menangani Cybercrime terhadap pelaku tindak pidana SARA di pilkada serentak 2018 para penegak hukum melakukan analogi atau perumpamaan dan persamaan terhadap pasal-pasal yang ada dalam KUHP biasanya digunakan lebih dari satu pasal. Penerapan pasal-pasal ini harus lebih tepat, sehingga sangat efektif dalam proses penegakan keadilan, namun disisi lain tidak melarang kebebesan berekpresi dan berpendapat. Pasal 28 ayat ( 2 ) Undang-Undang No 11 Tahun 2008 Tentang Informasi dan Transaksi Elektronik merupaka pasal yang paling tepat dalam menindak penyebaran kebencian disbanding pasal-pasal pidana lainya.

\section{DAFTAR PUSTAKA}

Soerjono Soekanto, Pokok-Pokok Sosiologi Hukum, (Jakarta Rajawali Pers, 1980)

Ahmad M. Ramli, 2004, Cyber Law dan Haki Dalam Sistem Hukum Indonesia, Bandung, Refika Aditama Barda Nawawi Arief, Perbandingan Hukum Pidana, (Jakarta: PT Raja Grafindo Persada, 2002) hlm: 259.

Phlipus M. Hadjon dan Tatiek Sri Djamati,. Argumentasi Hukum, Universitas Gajah Mada press, Yogyakarta, 2005

Abdul Manan, Aspek -Aspek Pengubah Hukum, Jakarta Kencana 2006

Ridwan HR , Hukum Administrasi Negara, Jakarta Rajawali pers, 2006, Zainudin Ali, Fisafat Hukum, Sinar Grafika: Jakarta, 2010

Sutarman,. Cyber Crime Modus Operandi dan Penanggulangannya, LaksBang PRESSindo, Yogyakarta, 2007,

Achmad Ali,. Menjelajahi Kajian Empiris Terhadap Hukum, Yasrif Watampone (anggota IKAPI), Jakarta, 1998,

Achmad Ali,. Menguak Teori Hukum (Legal Theory) dan Teori Peradilan (JudicialPrudence) 
Termasuk Interpretasi Undangundang (Legisprudence), Kencana Prenada Media Group, Jakarta, 2009

Satjipto Rahardjo,. Hukum dan Perilaku Hidup yang Baik adalah
Dasar Hukum yang Baik, Kompas, Jakarta,2009,

Dikdik M. Arief Mansur dan Elisatris Gultom,. Cyber Law-Aspek Hukum Teknologi Informasi, Refika Aditama, Bandung, 2005, 